\title{
Textual Analysis of the Jakarta Post Online Representation of Presidential Candidates in Indonesia
}

\author{
Prayudi \& Retno Hendariningrum \\ Universitas Pembangunan Nasional "Veteran" Yogyakarta \\ Email: yudhi_ahmad@yahoo.com
}

\begin{abstract}
General Election 2014 in Indonesia principally was a gate to more democratic Indonesia. People were given rights to directly vote their preferred legislative representatives and president and vice president for the next five-year period. New political learning process was introduced as all presidential candidates must show their capabilities in all aspects to attract constituents. The role of mass media became important as each candidate worked hard to gain sympathy from people. This paper examines how Indonesian online news media critically reported the presidential candidates. Further, this paper analysed how the issue were represented in the online media and why it was represented in such ways.
\end{abstract}

Keywords: general election, news media, textual analysis, presidential candidate, the Jakarta Post

\section{INTRODUCTION}

The election of Indonesian president and vice president held in 2014 has directly led to a political learning process. The president and vice president candidates must demonstrate their capability politically, socially and economically through programs offered if they later become the president and vice president. President and vice president candidates who merely accentuate self-image, for example, by relying on the former president's parents or grandchildren of the founders of largest mass organization, without offering policies to overcome crisis and restore the nation's socio-political conditions that affected how the international looks at Indonesia, they should not need to be supported. Way of thinking and support with blind fanaticism is supposed to be transformed into a logical rational. Thus, people should take a political decision that has to be considered carefully as it determines the fate of the nation for five years to come. The election of the president and vice president directly invites the public to vote for leaders they think are best to lead this nation.

In a broader context, the 2014 President and Vice President Election will greatly affect the shape of Indonesia's foreign relations with other countries. Concerns of some developed countries such as America and Australia with the possible emergence of strong military leadership, along with the rise of Gerindra party and Prabowo Subianto who is a former general in the era of Suharto's New Order, making the 2014 presidential election receives serious attention by some developed countries. Association of European Union countries, for example, felt the need to monitor the course of the 2014 election process. Foreign news media institutions also send their reporters to report the elections in Indonesia.

The emergence of these concerns at least is based on some arguments. First, it strongly relates 
to the threat of terrorism as a global phenomenon is assumed to come from a country where Muslim is majority such as Indonesia, Malaysia and some Arab countries such as Iraq and Afghanistan with Al Qaeda. The strengthening of Islamic parties is feared that it will bring traditional Islamic leadership style. Second, the participation of the president and vice president candidates with military background is feared that it will surface militaristic leadership style and thus bring Indonesia back into the era of the New Order authoritarian and bureaucratic. Consequently, the 2014 President and Vice President Election will be a representation of the run of the reform process which leads to a more democratic Indonesia.

The role of the news media becomes very significant in relation to the election. It is because presidential and vice presidential candidates who is supported by the success team will be competing to win public's support and sympathy, and news media is the right instrument. It is a challenge for the news media institutions to be able to keep a distance from various interests. It is expected that news media can convey information or messages independent, objective and value-free. Even if the mass media should be aligned, then the media should be oriented to the public interest. Thus, it is interesting how the presidential and vice presidential campaigns reported by the news media. It is also noteworthy why news media institutions tend to report the presidential and vice presidential campaign issue from particular point of view. This is principally based on an understanding that news media reporting can not be separated from the actual context that the news media attempt to construct, and at the same time this context also affects the way the media represents an issue in reporting.

According to Grossberg et al. (1998: 7),

the media can not be understood apart from an active relationship in which they are always involved: we can not understand the media regardless of the economic, political, historical and cultural contexts. We can not understand the media first and think about the influence of media on politics and economics. At the same time, we can not understand the political or economic events and then hope to understand the role of the media in representing these events. Thus, the meaning of a text representation is inversely related to its context.

In conjunction with the implementation of the 2014 presidential election, an understanding of how news media represents an election issue is an interesting discussion. This paper aims to analyze the portrayal of presidential candidate in the 2014 election in The Jakarta Post online.

\section{RESEARCH METHOD}

To get a thorough analysis of the text from The Jakarta Post Online, news textual analysis approach was used. Textual analysis is an interpretive research method that identifies the text in relation to the contextual background. This approach is based on the understanding that the construction of the text can not be separated from the relationship between media institutions and its social and cultural environment. Principally, the purpose of media texts analysis is to improve our understanding of the role played by the news media in constructing meaning within wider culture. Analysis of media texts always starts from the text to the wider culture or from text to audience (Cunningham and Turner, 1997).

Using this system of textual analysis of news items, this paper analysed how The Jakarta Post online represented news of presidential candidates as part of the 'fourth estate' role of the press through the interplay of cultural, political and organisational factors. Emphasis was given to headlines and text of news items that were considered important. Though only some part of the news items analysed were presented, principally the analysis covered the whole texts of the news items to extract stronger evidence. The process of textual analysis of the text is done by asking some questions as follows (Weber, 2004):

Goals. Why do media institutions write these stories? What kind of response does media expect from the audience? To answer these questions, developed a list of some possible goals possible. Then the text is reviewed. Identify evidence that can be found in the text that support the goals developed. It was only later developed the agenda of media institutions in drafting the text. 
Writer. What is known about the background, personality and socio-cultural perspectives (interests) of media institutions? What evidence can be found in the text? In this case describing general profile of the character, background and interests of media institutions is necessity. Then reviews the text and identify specific evidence to support the profile compiled. Finally, draw up a revised profiles that refer to specific evidence in the text.

Audience. Who is the target audience of the text? Why are certain audience interested in the text (news) written by media institutions? In answering this question, it is necessary to identify one or more audience of the text. In the process of identification, explain why a particular audience interested in the text. Then, text is reviewed. Finally, develop a description of the target text.

Technique. What means are used by the author to persuade or influence the reader? Consider techniques such as anecdotes, quotations of experts, statistics, figurative language (metaphors, symbolism, and allusion). Also note the three forms of persuasion: ethos (credibility), pathos (emotion), and logos (reason).

Context. When and where is the text written? What kind of themes and trends that occur when the text is written. That is, in the context of social, political and cultural such as what time the text was written. Susunlan some political context when the text was written. In response to the above questions, the researcher must be based on some common themes and trends. Then reviews the text and find specific supporting evidence.

\section{MASS MEDIA AND PRESIDENTIAL ELECTION}

News media coverage of an issue is principally a journalistic practice that cannot be separated from various influences such as the state, culture, ideology, editorial policy and the mission of media institutions. The interplay of these various factors is clearly implicated in the ways in which journalists and editors conduct their work - it clearly contributes to the selection of news issues and the ways in which the news is presented. While issues of 'intentionality' (what meanings are intended by a news practitioner) lie outside the scope of the current research, it is evident that texts are generated through the professional practices, priorities and cultural grounding of a news organisation and its practising professional staff. These priorities and practices are particularly pertinent for a study of terrorism (a highly problematic act of political violence) within an equally volatile social and political context - Indonesia in a state of transition. While seeking to contribute to the formation of a specifically Indonesian civil society, the news media under study are also subject to their own culturalideological priorities and predispositions. In this sense, these priorities problematise broader issues of news balance and objective reporting - critical elements of the news publications' fourth estate role. Cultural Studies provides a valuable theoretical framework for investigating the interplay of these various factors and the complex relationship between a news organisation's aspirations for objectivity and the inevitability of political positioning (Lewis, 2005; 12-32).

Mass Media has been described by Campbell as "the cultural industries-the channels of communication-that produce and distribute songs, novels, newspapers, movies, internet services, and other cultural products to large numbers of people" $(2003 ; 6)$. Based on this definition, mass media can be seen as a conduit through which information about culture is transmitted to potentially sizable audiences. Mass media, news media in particular, work through the dissemination of messages to public. In countries where democratic values are upheld and people have the right to seek, own, and disseminate information, the responsibility to inform public has made the press to freely inform news without afraid of being banned by the government (Prayudi, 2008).

Understanding entertainment media as one of the types of mass media, we can then see the campaign of presidential candidate within a frame of a drama. It can be said that the campaign of presidential candidate is a stage upon which political 'drama' is performed for specific audiences, (national or international publics, particular groups or individuals, or political elites) to achieve particular goals. Adopting the media triangle proposed by Lewis (2005), it is understood 
that the theatrical impact is created through the pressing crowd of reporters, camera crew and technicians sent to bring an event on to the screen. Media institutions have to compete with each other to give the best coverage of the event. At the same time, the media institutions have to consider various policies that come from the owner of the media, editorial board and government. They may also need to pay attention to unwritten policy that comes from society or interest groups. In some developing countries like Indonesia, interest groups can force their interest to the media which affect the way the media report an issue. Media institutions also need to consider their readers which later determine how the media convey their message. What cannot be ruled out, according to Whitaker, is at least the temptation to make the presidential candidate campaign so presentable in media-conventional terms that objectivity may take second place to the visually gripping (2004). It is sometimes remarked that the intentions of presidential candidates and of the media are similar. Both deal with publicity and will do their best to keep the story alive and exciting.

What is presented in the media contributes to how the audience form their opinion of the event. Media texts, added with information from past history of similar event have become the context of how audience respond to the terrorist event. At the same time, media responsibility to inform the public has given the terrorist the way to gain publicity. The rapid growth of telecommunication industries these days has resulted in events on one part of the world can be seen by audience at the exact same time on the other part through television set that receives signal via telecommunication satellite. The Gulf War in the 1990s is a good example of this and CNN Television Network determines itself as the global key player in media industries as the news television station. Through media, presidential candidates can increase the level of popularity which later creates acceptance within public. They can exploit far-reaching, instant, and even global media networks and information highways. Thus, it can be claimed that mass media principally plays different roles in reporting issue of presidential candidates. There are cultural, economic and political contexts that may affect the way mass media represents this issue.

\section{THE JAKARTA POST: NEWS POLICIES}

The Jakarta Post has a distinctive cultural, political and institutional-professional historyall of which contribute to the ways in which the newspaper reports and represents news events. Popularly known as 'The Post', this newspaper plays a significant role in the history of Indonesian news media. First published on 25 April 1983, the new English daily is unique, not only in its goals, which is to improve the standard of English language media in Indonesia, but also in bringing together four competing media publishers (Suara Karya, Kompas, Sinar Harapan and Tempo) into producing a quality newspaper with an Indonesian perspective. Ten percent of equity (later increased to 20 percent) was provided as a collective share of all employees (http://www.thejakartapost.com/ online_media_kit).

The objective of the news publication is to cater for the fast growing foreign community in Indonesia with English language. The objective is also to present to the public a newspaper of the highest quality that would provide its readers with all the news that was not only fit to print, but that would deepen their insight into the very workings of this vast archipelago, its people and its government, as members of the great family of nations. According to its own public pronouncements, this newspaper employs the highest standards of professional journalism, seeking to influence public opinion within and outside Indonesia.

According to its 2006 media kit, total daily average paid circulation of The Jakarta Post is around 35,000 copies. Meanwhile, the educational background of its readers shows that it is dominated by readers with postgraduate $(45.6 \%)$ and undergraduate $(35.9 \%)$. As of 5 nationalities that read The Post, Indonesian occupies the first rank with $45.2 \%$, followed by European (21\%); whereas Australian is the lowest with $4.2 \%$.

Going online has become a necessity for media businesses, as it connects the outlet to wider audiences and advertising revenues. Recent developments in Indonesia show that the Web is the future of news and information as evidenced by the increasing number of media publications available over the Internet. As the largest English newspaper in Indonesia, The Jakarta Post has 
anticipated this trend and provided the online version of the newspaper, thejakartapost.com. As the name suggests, it also offers breaking news and a wealth of information on Indonesia. By providing up-to-date, in-depth accurate information and analyses, thejakartapost.com aspires to be a onestop reference point on Indonesia that will serve both local and international audiences. Thus, what role did the Jakarta Post play in reporting the issue of presidential candidate? What were its policies in dealing with this issue?

In terms of news orientation, an interesting phenomenon appears in the news of presidential candidate that were published in the Jakarta Post online. Although only thirteen news items were found over a period of three months (JanuariyMarch 2014), but the critical nature of the media is very strong prominent in the news related to the presidential candidate in Indonesia. This is alo strengthened with one editorial.

Particularly, The Post gave attention more on the election of Jokowi, Jakarta's recent governor, as the presidential candidate from the Indonesian Democratic Party of Struggle (PDIP) and the Democratic Party (PD) presidential convention. Meanwhile, other presidential candidates from the Welfare Justice Party (PKS), Prabowo of Gerindra Party, and Suryadharma of the United Development Party (PPP) were reported once by The Post.

The Post's reporting of presidential candidate from PDIP appeared in four news items: PDI-P to decide presidential candidate in April (05/01/2014), Euphoria on Jokowi too early (14/03/2014), It's official: Jakarta Governor Jokowi will run for president (15/03/2014), and Jokowi must get permission from President for his candidacy: Gamawan (15/03/2014). News items indicated these issues are as follow

\section{PDI-P to decide presidential candidate in April}

The Indonesian Democratic Party of Struggle (PDI-P) will decide on its presidential and vice presidential candidates in April, or after the general election to select members of the House of Representatives (DPR), the Regional Representatives Council (DPD) and the Regional Legislative Council (DPRD), a senior party official has said.
"We will decide who will be nominated as presidential and vice presidential candidates in April, or after the legislative election on April 9," PDI-P secretary-general Tjahjo Kumolo said in Semarang on Sunday as quoted by Antara news agency.

According to Tjahjo, the timeframe needed to be conveyed to the public following speculation that the PDI-P would declare its candidates in January to coincide with the party's anniversary. (The Jakarta Post, 05/01/2014)

\section{It's official: Jakarta Governor Jokowi will run for president}

After a long wait and endless speculation, the Indonesian Democratic Party of Struggle (PDI-P) has finally announced what many had predicted: the nomination for president of Jakarta Governor Joko “Jokowi” Widodo.

PDI-P deputy secretary-general Puan Maharani made the announcement at the party's central board headquarters in Lenteng Agung, South Jakarta, on Friday by reading out an official letter of instruction handwritten by her mother, PDI-P chairwoman Megawati Soekarnoputri, during a press conference.

"I want all elements within the nation to fully support Joko Widodo as the official presidential candidate of the PDI-P," Puan said while quoting Megawati's instructions. "All PDI-P members must also do their best to ensure our victory in the legislative election by closely monitoring each ballot station to prevent fraud and intimidation in any form."

Due to the growing popularity of Jokowi, numerous elements within the PDI-P have been pushing Megawati to seize the moment by officially announcing him as a presidential candidate so that the party can gain a major advantage during the legislative election and, thereby, secure a large proportion of the seats at the legislative level. (The Jakarta Post, 15/03/2014) 
Based on the two news items above, The Post represented the election process of PDIP's presidential candidate. While in January 2014 PDIP had stated that it would determine its predsidential candidate after the legislative election; further development and the moment to win the legislative election on 9 April 2014 had made PDIP to change its decision. Considering political polls and surveys that tended to place Jookowi in the top rank, Megawati had put aside her willingness to run for the president and gave the place to PDIP most potential and popular cadre, Jokowi. PDIP had calculated the possibility of Jokowi to be the president. This representation was done by quoting the statements of the PDIP officials and then contrasting them with statements from other social and political observers. In other words, The Post adopted a posture of 'balanced reporting', allowing the readers to judge the different perspectives that were presented. The goal for this reporting was to show the big shift of PDIP's presidential candidate. It is unfortunate, however, that the Post did not portray Megawati statement that reminded him that he is a cadre of PDIP if he becomes the president. The construction of this issue can be contradicted with statement from political analysts that stated once a person becomes the president, he or she must not represent political interest of the political party. Why the Post did not report this? One of the Post journalist argued,

We have a strong editorial stand. We are taking no sides except in terms of our primary principle which is to present news based on professional journalistic standards. The Post professionally reported the events without having any intention to discredit any parties (interviewed with the Post journalist, name to be anonymous, 2014).

Jokowi has topped public opinion polls as the most electable candidate in the upcoming presidential election. He managed to gain national and international recognition after his successful tenure as major of Surakarta, a city in central Java Province. The PDI-P then backed him in the Jakarta governor race, which he won with ease. His popularity is driven by his humble personality and clean track record. He is also popular among the PDI-P grassroots because many consider him to be a true Marhaenis. Marhaenism was a socialist ideology conceived by Sukarno (The Jakarta Post, 14/03/2014). Apart from the choosen of Jokowi as the PDIP's presidential candidate, The Post warned its readers not to speculate further as appeared in Euphoria on Jokowi too early (14/03/2014).

On the other hand, The Post represented the Democratic Party's presidential candidature process as going nowhere. This, for instance, can be seen from the news item as follows

\section{Waning electability overshadows Dems, presidential convention}

The Democratic Party's (PD) presidential convention seems to be going nowhere with a senior party member admitting the ruling party might not be able to field a candidate in the July presidential election. EE Mangindaan, the executive chairman of the party's board of patrons, said his party would likely garner less than 25 percent of the vote in the April 9 legislative election, which was far below the electoral threshold to nominate a presidential candidate.

"Let's be realistic. If we only got 7 or 10 percent, how would we be able to nominate a presidential candidate?" Mangindaan, who is also transportation minister, said as quoted by Kompas.com.

The Election Law stipulates that a party must gain at least 25 percent of popular vote or control 20 percent of the seats at House of Representatives to be able to field a candidate. Several of the convention's contenders were disappointed by his statement, and feared that it would discourage the participants and their supporters. "He should not have expressed something so negative. A senior PD member like him should be injecting a more positive attitude," participant Ali Masykur Musa, who is also a member of the Supreme Audit Agency (BPK), said.

The organizing committee for the convention has been languishing to keep the convention running since it was launched in August 
last year amid financial constraints. The committee recently admitted that it could not afford to air the presidential debates of the convention participants. Convention participant Anies Baswedan questioned the purpose of holding the debates if they were not televised nationwide. "People vote after comparing candidates. How could they vote if they never see the candidates?"

The problem was made worse by the recent resignation of a key committee member, Effendi Ghazali, a political communication expert from the University of Indonesia. Many believe that Effendi resigned due to unfair practices within the committee. Effendi is a non-partisan and well-known political communications expert.

As many as 11 public figures have participated in the convention. The decision on the party's eventual presidential candidate will be in the hands of three independent survey institutes hired by the PD and is due to be announced soon after the April 9 legislative election. (The Jakarta Post, 15/03/2014)

The slow process of the Democratic Party's presidential convention has made The Post to report this issue. Holding on the principle of 'fair and balance', The Post reported the conflict that rose within the convention. Using various news sources that came from within and outside the Democratic Party (Partai Demokrat or PD), The Post principally attempted to practice news media as'the fourth estate' and let its cirtical readers which was dominated by foreigners to draw conclusion from the text. The fourth estate is a term that positions the press as a fourth branch of government and one that is important to a functioning democracy.

In particular, The Post emphasized on the difficulties that PD faced to elect its presidential candidate after Soesilo Bambang Yudhoyono was no longer allowed to be elected as the presidential candidate after two period of being the president. The Post constructed the news by quoting statement of the executive chairman of the party's board of patrons. Through this statement, the Post resepresnted how PD realised that it would be difficult to win the legislative election and therefore it had created a stagnant condition regarding presidential candidate from $\mathrm{PD}$.

With many of its party members involved in corruption cases and its former chairman Anas Urbaningrum was also arrested for corruption, PD seemed found difficulty gaining back its popularity. And the slow process of presidential convention had only worsened the situation for the PD. Nonetheless, the PD had decided that it would only inform its presidential candidate after legislative election. One thing that the Post paid attention to in PD's presidential candidate election was the hiring of three independent survey isntitue to determine suitable presidential candidates through convention process. This was represented in Dem's presidential candidate from convention only, Pramono says (09/03/2014), Dems to name presidential candidate after legislative election $(15 / 03 / 2014)$. Conflicted statements can be seen as follow

\section{Dem's presidential candidate from convention only, Pramono says}

Former Army chief of staff Gen. (ret) Pramono Edhie Wibowo affirmed that the Democratic Party (PD) should not nominate a presidential candidate that was not involved its presidential convention. "The Democratic Party is the first party in Indonesia to select a presidential candidate through this system, which was open to non-party members too," he said in a media statement Sunday...

Pramono's statement was made in response to a comment made by on of the Indonesian Democratic Party of Struggle (PDI-P) founder, Sabam Sirait, who suggested that Democratic founder, high-council chief, chief patron and chairman Susilo Bambang Yudhoyono should select a presidential candidate from outside the party as there were no capable applicants. (The Jakarta Post, 09/03/2014) 
Through this reporting, the Post attempted to describe the worsening condition faced by PD. Apart from the issue above, the Post reported the complexity faced by PD as none of its cadre eligible for the presidential position. Thus, presidential convention was a way out of the scarcity of presidential candidate inside the party. To construct the news and gave a description of news complexity, the Post quoted statement of higher ranking official of competing party in the presidential election, PDIP.

The Post preferred non partisan position in its reporting of the issue. According to the Post Managing Editor, "It is one of the ways of our responsibility to society. We represent the issue because that's the facts and those facts are important for the society to know. In our understanding, once we have been able to show our responsibility to public, then the role and function of the news media become stronger (in Prayudi, 2010: 182).

Thus, it can be concluded that the representation of the issue was The Jakarta Post's attempt to play its role as the news media where it portrayed how the Democratic Party dealt with issue of presidential election. Through this representation, The Post wanted to educate society to become aware of the presidential election. The neutral position it took also signifies the independency of this news media institution from the attempts of news media owners to have affiliation with politicians from political parties. Through the representation of presidential candidates, The Post wanted to show to its readers how political parties in Indonesia dealt with presidential election, the process of presidential candidate election within the party and the complexity faced within the party during the process of candidate election.

In brief, the research result shows that principally The Jakarta Post online played the role as storyteller in representing the issue of presidential election. It was done by implementing the $5 \mathrm{~W}+\mathrm{H}$ formula, up-side-down pyramid, news values and worthiness as part of the professional journalistic standard. The facts of events were written as information based on a set of frameworks which state that the news reported should not mislead its readers or condemn people or parties involved in the matter. It should hold the presumption of innocence, place the matter in the way it really stands, involve the choice of relevant and balanced news sources, and always confirm the information gathered. Thus, as Cultural Studies proposes, the news media institutions cannot ignore the interplay of various levels of influence of organisational as well as cultural and political influences.

\section{CONCLUSION}

As the news media institution published by four competing media publishers, the Jakarta Post has turned into a quality, broadsheet newspaper with a distinctive Indonesian perspective to counter the highly unbalanced western dominated global traffic of news and views. In relation to the representation of Indonesia's presidential candidate, The Post carefully reported the issue. With strong editorial stand, The Post had taken no sides and presented a balanced perspective in accordance with its editorial policy and the standards of the fourth estate.

The Post represented the issues above trough open, straight forward, and critical reporting style which is new characteristics of Indonesian press in the era of 'reform' (reformasi). In this sense, The Post contributed directly to fourth estate functions of effective, secular governance in accordance with the pluralist ideals of the Indonesian Constitution and its supporting framework, Pancasila. Through these representations, the Jakarta Post had been able to show its social responsibility to the public.

\section{BIBLIOGRAPHY}

Campbell, R. (2003). Media and Culture: An Introduction to Mass Communication. New York: Bedford-St. Martin's Press.

Cunningham, S. \& G. Turner. (1997). The Media In Australia: Industries, Texts, Audiences (2 edition). Allen \& Unwin: St Leonards, NSW.

Grossberg, L., E. Wartella \& D. C. Whitney. (1998). Mediamaking: Mass Media in A Popular Culture, Sage Publications Inc.: California.

Lewis, J. (2005). Language Wars: the Role of the Media and Culture in Global Terror and Political Violence. London: Pluto Press.

Prayudi. Analisis Tekstual: Pemahaman Akademis. Jurnal Ilmu Komunikasi. Jurusan Ilmu Komunikasi, FISIP UPN "Veteran” Yogyakarta. Terakreditasi, ISSN 1693-3029. Volume 3, No. 
2, Mei-Agustus 2005.

. (2010). Terror In Indonesia: Terrorism And The Representation Of Recent Terrorist Attacks In Three Indonesian News Publications Within A Context Of Cultural And Social Transition, Unpublished Dissertation, RMIT University: Melbourne, Australia.

The Jakarta Post. PDI-P to decide presidential candidate in April. 05 January 2014.

. Euphoria on Jokowi too early. 14 March 2014.

. It's official: Jakarta Governor Jokowi will run for president. 15 March 2014.

. Jokowi must get permission from President for his candidacy: Gamawan. 15 March 2014.
Waning electability overshadows Dems' presidential convention. 15 March 2014.

. Dem 's presidential candidate from convention only, Pramono says. 09 March 2014.

. Dems to name presidential candidate after legislative election. 15 March 2014.

www.thejakartapost.com/online_media_kit

Utah Valley State College Writing Centre. Questions for Textual Analysis. [Online]. Available: http:// weber.ucsd.edu/ jhughes/analysis.html [2004, 21 March]

\section{WEB SITE:}

Questions for Textual Analysis, [Online]. Available at: http://www.weber.uesd.edu/ jhughes/ analysis.html [2004, 21 Maret] 